\title{
Commentary: Tissue valves--One more reason to stay on top of your cholesterol
}

\author{
William E. Stansfield, MD, CM, FACS
}

\author{
From the Department of Surgery, University of Toronto, Toronto, Ontario, Canada. \\ Disclosures: Author has nothing to disclose with regard to commercial support. \\ Received for publication Dec 31, 2018; accepted for publication Jan 1, 2019; available ahead of print Feb 14, \\ 2019. \\ Address for reprints: William E. Stansfield, MD, CM, FACS, Department of Surgery, University of Toronto, 401 \\ Wellesley St E, Toronto, Ontario M4X1H5, Canada (E-mail: wstansfi@gmail.com). \\ J Thorac Cardiovasc Surg 2019;158:744-802 \\ $0022-5223 / \$ 36.00$ \\ Copyright (c) 2019 by The American Association for Thoracic Surgery \\ https://doi.org/10.1016/j.jtcvs.2019.01.003
}

The risks of long-term anticoagulation are leading to aortic tissue valves being implanted in younger and younger patients, even though guidelines consistently recommend mechanical valves for most patients younger than 60 years old. $^{1,2}$ The main concern with bioprosthetic valves is durability, with the consequent potential need for reoperation. Now, with transcatheter valves taking the surgical world by storm and the promise of valve-in-valve replacement, do we still need to worry about redo valve surgery? While we wait for the future, we can best help our current patients by ensuring that existing bioprostheses last as long as possible. That is the aim of the article by Lee and colleagues ${ }^{3}$ in this issue of the Journal.

Lee and colleagues ${ }^{3}$ demonstrate that induced hypercholesterolemia in rats causes a systemic inflammatory state, with elevated levels of serum interleukin 6. The implanted valve samples show localized inflammatory effects, with macrophage infiltration, increased interleukin 6 and bone morphogenetic protein 2 detected by immunohistochemistry and Western blot, and calcification. Serum cholesterol, and all related changes, are substantively reduced by statin treatment. The same findings are reproduced in 4 different brands of tissue valve. The rat dose of statin per kilogram is much greater than the human dose, but the effect on serum cholesterol is similar to that of high-dose statins in human patients.

The main limitation of the experiment is that it cannot separate out the anti-inflammatory effects of statins from the effects on serum cholesterol; that is, it cannot tell us whether statins would be beneficial when serum cholesterol is normal. Indeed, in this group's previous work, they found no statin effect in rats with normal cholesterol. ${ }^{4}$ Still, it is quite meaningful that researchers studying valve calcification in laboratory animals use hypercholesterolemia to accelerate valve failure. ${ }^{5}$

This relationship between cholesterol and valve calcification has similarly been identified in human studies. In the early 2000s, high serum cholesterol was correlated with decreased aortic valve area ${ }^{6}$ and the necessity for

\section{References}

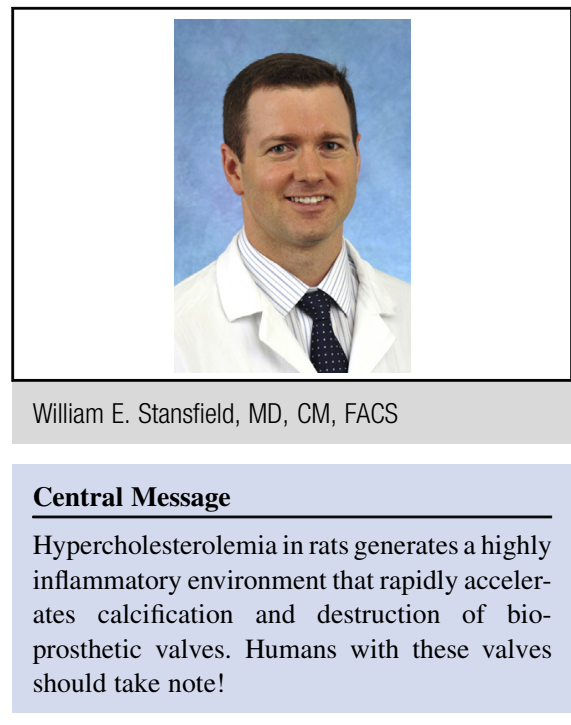

See Article page 731 .

bioprosthetic valve explantation. ${ }^{7}$ These studies included patients with serum cholesterol levels greater than $200 \mathrm{mg} / \mathrm{dL}(5.2 \mathrm{mmol} / \mathrm{L})$, very different from values in the current era of stringent cholesterol management. Subsequent prospective studies failed to demonstrate benefits of statin therapy in native valve sclerosis. ${ }^{8,9}$ Retrospective reviews were undertaken to determine whether the protective effect of statins would be more identifiable in bioprosthetic valves, but they were confounded by selection bias. In the largest review, patients with bioprosthetic valves treated with statins had nearly the same cholesterol levels as patients who did not receive statins. ${ }^{10}$ Not surprisingly, the outcomes of the 2 groups were the same. Rather than conclude that statins do not affect valve durability, it would be more consistent to surmise that normalizing cholesterol normalizes the risk of valve failure. Bravo to the clinicians managing those patients effectively!

As we work to individualize patient care, it behooves us to use all the data available to make informed decisions. One animal study does not change surgical practice, but it does highlight clinical risks. This allows us to act, inform our patients, and maybe help a few valves last a little longer.

1. Nishimura RA, Otto CM, Bonow RO, Carabello BA, Erwin JP III, Guyton RA, et al; American College of Cardiology; American College of Cardiology/ 
American Heart Association; American Heart Association. 2014 AHA/ACC guideline for the management of patients with valvular heart disease: a report of the American College of Cardiology/American Heart Association task force on practice guidelines. J Thorac Cardiovasc Surg. 2014;148:e1-132. Erratum in: J Thorac Cardiovasc Surg. 2014;148:1763.

2. Isaacs AJ, Shuhaiber J, Salemi A, Isom OW, Sedrakyan A. National trends in utilization and in-hospital outcomes of mechanical versus bioprosthetic aortic valve replacements. J Thorac Cardiovasc Surg. 2015;149:1262-9.e3.

3. Lee S, Kim D-H, Youn Y-N, Joo HC, Yoo K-J, Lee SH. Rosuvastatin attenuates bioprosthetic heart valve calcification. J Thorac Cardiovasc Surg. 2019;158: 731-41.e1.

4. Lee SH, Kim DH, Youn YN, Lee S, Joo HC, Chang BC, et al. Effect of rosuvastatin on bovine pericardial aortic tissue valve calcification in a rat subdermal implantation model. Korean Circ J. 2017;47:401-8.

5. Lorusso R, Corradi D, Maestri R, Bosio S, Curulli A, Beghi C, et al. Atorvastatin attenuates post-implant tissue degeneration of cardiac prosthetic valve bovine pericardial tissue in a subcutaneous animal model. Int J Cardiol. 2010;141:68-74.
6. Palta S, Pai AM, Gill KS, Pai RG. New insights into the progression of aortic stenosis: implications for secondary prevention. Circulation. 2000;101:2497-502.

7. Farivar RS, Cohn LH. Hypercholesterolemia is a risk factor for bioprosthetic valve calcification and explantation. J Thorac Cardiovasc Surg. 2003;126 969-75.

8. Rossebø AB, Pedersen TR, Boman K, Brudi P, Chambers JB, Egstrup K, et al. SEAS Investigators. Intensive lipid lowering with simvastatin and ezetimibe in aortic stenosis. N Engl J Med. 2008;359:1343-56.

9. Chan KL, Teo K, Dumesnil JG, Ni A, Tam J, ASTRONOMER Investigators. Effect of lipid lowering with rosuvastatin on progression of aortic stenosis: results of the Aortic Stenosis Progression Observation: Measuring Effects of Rosuvastatin (ASTRONOMER) trial. Circulation. 2010;121 306-14.

10. Kulik A, Masters RG, Bédard P, Hendry PJ, Lam BK, Rubens FD, et al Postoperative lipid-lowering therapy and bioprosthesis structural valve deterioration: justification for a randomised trial? Eur J Cardiothorac Surg. 2010; 37:139-44. 